\title{
Structural Design, Synthesis and Antioxidant, Antileishmania, Anti-Inflammatory and Anticancer Activities of a Novel Quercetin Acetylated Derivative
}

\author{
Saul Vislei Simões da Silva ${ }^{1}$, Orlando Maia Barboza ${ }^{1}$, Jéssica Teles Souza ${ }^{2}$, Érica Novaes Soares ${ }^{2}$, \\ Cleonice Creusa dos Santos ${ }^{2}$, Luciano Vasconcellos Pacheco ${ }^{1,3}$, Ivanilson Pimenta Santos ${ }^{3}$, \\ Tatiana Barbosa dos Santos Magalhães ${ }^{1}$, Milena Botelho Pereira Soares ${ }^{3,4}$, Elisalva Teixeira Guimarães ${ }^{1,3}$, \\ Cássio Santana Meira ${ }^{1,3,4}$, Silvia Lima Costa ${ }^{2}$, Victor Diógenes Amaral da Silva ${ }^{2}$, \\ Lourenço Luís Botelho de Santana ${ }^{1}$ and Aníbal de Freitas Santos Júnior ${ }^{1, *}$ (i)
}

check for updates

Citation: da Silva, S.V.S.; Barboza, O.M.; Souza, J.T.; Soares, É.N.; dos Santos, C.C.; Pacheco, L.V.; Santos, I.P.; Magalhães, T.B.d.S.; Soares, M.B.P.; Guimarães, E.T.; et al. Structural Design, Synthesis and Antioxidant, Antileishmania, Anti-Inflammatory and Anticancer Activities of a Novel Quercetin Acetylated Derivative. Molecules 2021, 26, 6923. https://doi.org/10.3390/ molecules 26226923

Academic Editors: Jianbo Xiao and H. P. Vasantha Rupasinghe

Received: 19 October 2021

Accepted: 14 November 2021

Published: 17 November 2021

Publisher's Note: MDPI stays neutral with regard to jurisdictional claims in published maps and institutional affiliations.

Copyright: (c) 2021 by the authors. Licensee MDPI, Basel, Switzerland. This article is an open access article distributed under the terms and conditions of the Creative Commons Attribution (CC BY) license (https:// creativecommons.org/licenses/by/ $4.0 /)$.
1 Department of Life Sciences, State University of Bahia (UNEB), Salvador 41150-000, BA, Brazil; saulvislei@gmail.com (S.V.S.d.S.); orlandmb0@gmail.com (O.M.B.); lucianofcd@hotmail.com (L.V.P.); tatibasa@hotmail.com (T.B.d.S.M.); etguimaraes@uneb.br (E.T.G.); cassio.meira@fieb.org.br (C.S.M.); lourencoluisbotelho@gmail.com (L.L.B.d.S.)

2 Laboratory of Neurochemistry and Cell Biology, Department of Biochemistry and Biophysics, Federal University of Bahia, Salvador 40231-300, BA, Brazil; telles.jessica@hotmail.com (J.T.S.); ericanovaessoares@gmail.com (É.N.S.); cleonicemev@gmail.com (C.C.d.S.); costasl@ufba.br (S.L.C.); vdsilva@ufba.br (V.D.A.d.S.)

3 Gonçalo Moniz Institute, FIOCRUZ, Salvador 40296-710, BA, Brazil; eagle_nito@hotmail.com (I.P.S.) milena@bahia.fiocruz.br (M.B.P.S.)

4 SENAI Institute of Innovation in Health Advanced Systems (CIMATEC ISI SAS), University Center SENAI/CIMATEC, Salvador 41650-010, BA, Brazil

* Correspondence: anibaljrr@uol.com.br or afjunior@uneb.br; Tel.: +55-71-3117-5313

\begin{abstract}
Quercetin (Q) is a bioflavonoid with biological potential; however, poor solubility in water, extensive enzymatic metabolism and a reduced bioavailability limit its biopharmacological use. The aim of this study was to perform structural modification in $Q$ by acetylation, thus, obtaining the quercetin pentaacetate (Q5) analogue, in order to investigate the biological potentials (antioxidant, antileishmania, anti-inflammatory and cytotoxicity activities) in cell cultures. Q5 was characterized by FTIR, ${ }^{1} \mathrm{H}$ and ${ }^{13} \mathrm{C}$ NMR spectra. The antioxidant potential was evaluated against the radical ABTS ${ }^{\bullet+}$. The anti-inflammatory potential was evaluated by measuring the pro-inflammatory cytokine tumor necrosis factor (TNF) and the production of nitric oxide (NO) in peritoneal macrophages from BALB/c mice. Cytotoxicity tests were performed using the AlamarBlue method in cancer cells HepG2 (human hepatocarcinoma), HL-60 (promyelocytic leukemia) and MCR-5 (healthy human lung fibroblasts) as well as the MTT method for C6 cell cultures (rat glioma). Q and Q5 showed antioxidant activity of $29 \%$ and $18 \%$, respectively, which is justified by the replacement of hydroxyls by acetyl groups. $\mathrm{Q}$ and Q5 showed concentration-dependent reductions in NO and TNF production $(p<0.05) ; \mathrm{Q}$ and Q5 showed higher activity at concentrations $>40 \mu \mathrm{M}$ when compared to dexamethasone $(20 \mu \mathrm{M})$. For the HL-60 lineage, Q5 demonstrated selectivity, inducing death in cancer cells, when compared to the healthy cell line MRC-5 $\left(\mathrm{IC}_{50}>80 \mu \mathrm{M}\right)$. Finally, the cytotoxic superiority of Q5 was verified $\left(\mathrm{IC}_{50}=11 \mu \mathrm{M}\right)$, which, at $50 \mu \mathrm{M}$ for $24 \mathrm{~h}$, induced changes in the morphology of C6 glioma cells characterized by a round body shape (not yet reported in the literature). The analogue Q5 had potential biological effects and may be promising for further investigations against other cell cultures, particularly neural ones.
\end{abstract}

Keywords: quercetin; synthesis; quercetin pentaacetate; antioxidant; antileishmania; anti-inflammatory; cytotoxicity activity 


\section{Introduction}

Quercetin is a bioflavonoid with a proven impact on health and well-documented biochemical activities. This compound is considered one of the most potent antioxidants among polyphenols [1-3]. Due to its properties, quercetin has been tested for various therapeutic applications, such as antioxidant, antiparasitic, anti-inflammatory and anticancer activities $[4,5]$. In parasitic diseases, flavonoids are a high interest group. This is due to their low toxicity in hosts and several mechanisms by which they can modulate pathologically altered processes during infections [6]. Flavonoids have multiple targets for treating leishmaniasis and include targets, such as arginase, ribonucleotide reductase and topoisomerase II $[7,8]$.

Quercetin has multiple anticancer activities in several types of solid tumors. Furthermore, it has been proven to have activity in HL-60 cells (originating from acute myeloid leukemia (AML)) to significantly reduce tumor growth by reducing intratumoral oxidative stress, activation of the Extracellular Regulated Kinase (ERK) signal and subsequent apoptosis [9]. Quercetin improved the pro-inflammatory response by reducing IL-6 and TNF expression with positive anti-inflammatory activity in human THP1 macrophage populations [10].

Among the different types of cancer, glioma is one of the most aggressive and with poor prognosis. Unfortunately, main therapies (surgical removal, radiation therapy and chemotherapy) are not efficient. The average of overall survival for patients remains at approximately 14 months [11]. Nevertheless, new compounds, such as temozolomide [12], retinoids [13] and flavonoids [14] have shown anti-glioma activity. The antitumoral effects of quercetin have been described against cells from glioblastoma, which is the most aggressive of the gliomas [15].

Abnormal immune responses are involved in the initiation and development of a large number of diseases, including autoimmune diseases, allergies, cancer and neurodegenerative diseases. Flavonoids have potential immunomodulatory activity and are studied as alternatives for clinical use. Quercetin can exert significant immunomodulatory effects on the cellular production of cytokines derived from the Th- 1 and Th-2 profile and lymphocytic proliferation, regulating cellular immunity [16]. Furthermore, quercetin can differentially modulate the expression of interleukin genes in peripheral blood mononuclear cells (PBMC), favoring the Th-1 profile, which promotes cellular immunity by interferon gamma (IFN- $\gamma$ ), the reduction of the Th-2 profile involved in humoral immunity and macrophage activation by IL-4 [17].

The 1-ow water solubility, extensive metabolism and enzymatic degradation limit bioavailability and reduce the biopharmacological use of quercetin as a therapeutic agent [13]. An interesting approach to overcome the low bioavailability of polyphenols, in order to test and explore their in vivo activity, is the chemical modification of the natural compound, increasing solubility and slowing down metabolism. Thus, many synthetic routes are being studied, such as acetylation, addition of amines and bromination, modification to oximes and complexation with hydrazines [18-20].

In this study, we perform a structural modification in quercetin, aiming to obtain the analogue quercetin pentaacetate (Q5) for evaluation of the antioxidant potential, anti-inflammatory activity and inhibition of the growth of cancer cells, hepatocarcinoma (HepG2), promyelocytic leukemia (HL-60) and rat glioma (C6) cells.

\section{Results and Discussion}

\subsection{Synthesis and Characterization}

For the synthesis of the analogue quercetin $\left(3,3^{\prime}, 4^{\prime}, 5,7\right.$-pentaacetate), the total acetylation approach was used, which was adapted to the experimental conditions found in the literature [21]. In this way, acetic anhydride is preserved as an acylating agent and pyridine as a catalyst.

The product obtained (Q5), a yellow solid, was characterized featuring melting points in the range of $178-186^{\circ} \mathrm{C}$, compatible with the literature data [18]. Additionally, the com- 
parative analysis of the FTIR between quercetin and the product demonstrated the absence of absorption bands in $3400 \mathrm{~cm}^{-1}$ characteristic of quercetin hydroxyls and by the appearance of bands around $1600-1650 \mathrm{~cm}^{-1}$ indicative of carbonyl ester, demonstrating the replacement of hydroxyl groups by acetyl groups: IR $(\mathrm{KBr}) \vee\left(\mathrm{cm}^{-1}\right): 1761,1652,1615,1505$, 1442, 1377, 1208, 1176, 1121, 1085, 1012, 892, 837, 691 and 600 (Figure 1). The spectra were comparable with those described in the literature [21].
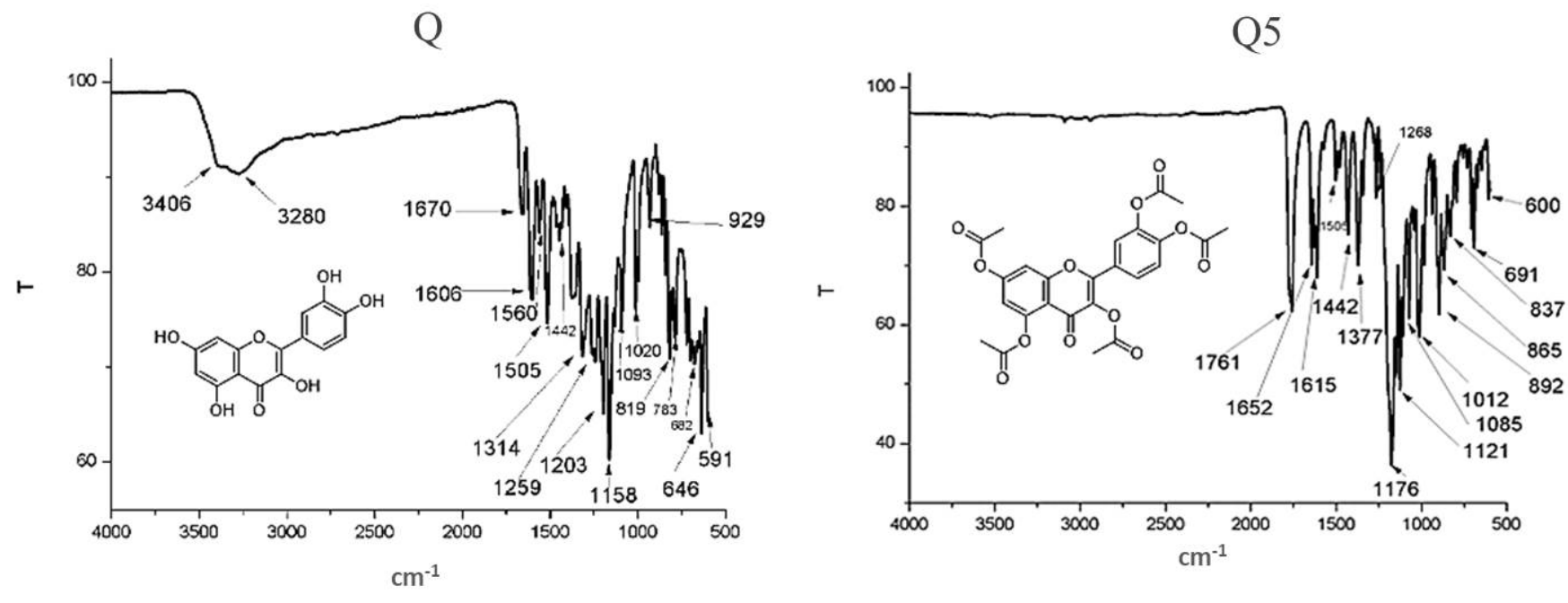

Figure 1. FTIR spectrum of the compounds Quercetin (Q) and Quercetin pentaacetate (Q5), demonstrating the disappearance of representative hydroxyl bands next to $3280 \mathrm{~cm}^{-1}$ and the appearance of bands close to $1761 \mathrm{~cm}^{-1}$ assigned to acetyl groups.

Nuclear magnetic resonance (NMR) analyses of the quercetin (Q) and product obtained (Q5) showed total acetylation, with the disappearance of singlets characteristic of hydroxyls above 9 ppm in the ${ }^{1} \mathrm{H}$ NMR spectrum (Supplemental Figures S1, S2 and S4-S6) and the appearance of large and characteristic signals of methyl in the aliphatic regions of the spectrum, between 2 and 3 ppm. For the ${ }^{13} \mathrm{C}$ NMR spectrum (Supplemental Figures S3 and S7-S9), the product obtained showed an increase in the representative signals of the ester carbonyls close to $170 \mathrm{ppm}$ and the arising of signals between 20 and $21 \mathrm{ppm}$ corresponding to the chemical shifts of the five aliphatic carbons of methyls, verified through the integral of the signals. The spectra were comparable with those described in the literature [22].

Biasutto et al. [23] were pioneers in the investigation of precursors based on esters, in order to increase the bioavailability of quercetin. Based on their studies, Mattarei et al. [21] promoted the total acetylation of quercetin and obtained the Q5 derivative in high yield (79-97\%). More recently, Mohajeri et al. [24] obtained a yield of $85 \%$ in obtaining analogue $\mathrm{Q} 5$, under heating $\left(180^{\circ} \mathrm{C}\right.$ for $\left.6 \mathrm{~h}\right)$. In the present study, the synthesis of Q5 was efficient, and we obtained one compound duly characterized according to the data described in the literature.

\subsection{Antioxidant $A B T S^{\bullet+}$ Radical Activity}

The comparative analysis of the antioxidant activity of $Q$ and $Q 5$ showed that quercetin (Q) was more active in scavenging the $\mathrm{ABTS}^{\bullet+}$ radical than Q5 (29\% and $18 \%$, respectively), with $\mathrm{IC}_{50}$ values (in $\mu \mathrm{M}$ ) of $188.850 \pm 0.003$ and $379.560 \pm 0.004$ for $Q$ and $Q 5$, respectively.

The antioxidant activity of flavonoids is directly related to their molecular structure. There are two mechanisms through which phenolic compounds can exert their antioxidant functions: hydrogen atom transfer and electron donation [25]. Quercetin's superior antioxidant activity can be attributed to the significant contribution of hydroxyls and their hydrogens, which are replaced by acetyls in Q5 analogue, thus, decreasing the capacity for hydrogen donation or free radical scavenging by synthetic molecules.

No data were found in the scientific literature reporting the antioxidant activity of the Q5 compound. Oh et al. [26] evaluated quercetin ester preparations and their antioxidant 
activities, showing that quercetin had the highest radical scavenging activity among the tested samples. Therefore, the high contribution of the hydroxyl groups in the antioxidant activity of quercetin are essential [27].

\subsection{Antileishmania Activity}

In order to evaluate the activity of the compound ( $Q$ and Q5) against the promastigote forms of the two Leishmania species, the $50 \%$ inhibitory concentration (IC50) was calculated from the cell viability assay in axenic culture. For Leishmania braziliensis, Q and Q5 had $\mathrm{IC}_{50}$ values $>100 \mu \mathrm{M}$ when compared to amphotericin B (IC501.1 $\mu \mathrm{M} \pm 0.1$ ). In addition, the effects of Q5 on the promastigote forms of L. amazonenses were evaluated, and this compound exhibited a lower $\mathrm{IC}_{50}$ value $(75.1 \pm 4.7 \mu \mathrm{M})$ for this species compared to L. braziliensis.

Tasdemir et al. [8] compared the antitrypanosome and antileishmanial activities of flavonoids and their analogues (derived from quercetin) and found them to be potent and effective antiprotozoal agents against amastigote forms of L. donovani $\left(\mathrm{IC}_{50}=1.0 \mu \mathrm{g} \mathrm{mL}{ }^{-1}\right)$. For promastigote forms of L. amazonensis, Fonseca and Silva et al. [27] found $\mathrm{IC}_{50}=31.4 \mu \mathrm{M}$ in cultures treated with quercetin within $48 \mathrm{~h}$. Furthermore, they reported complete cell growth arrest with $96 \mu \mathrm{M}$ quercetin in $96 \mathrm{~h}$, demonstrating satisfactory antileishmanicidal activity. Cataneo et al. [28] evaluated the antipromastigote effect of quercetin (up to $192 \mu \mathrm{M})$ against L. brasiliensis, in peritoneal cells of macrophages. In promastigote cultures of L. major, quercetin and its analogue quercetin-pentaacetate showed a concentrationdependent effect $\left(\mathrm{IC}_{50}=2.5 \pm 0.92\right.$ and $2.85 \pm 0.99 \mu \mathrm{M}$, respectively [24].

Some authors have shown that quercetin induces death in $\mathrm{L}$ amazonensis promastigotes through mitochondrial membrane dysfunction resulting from the production of reactive oxygen species [27,28] and other targets, such as arginase [7], ribonucleotide reductase $[8,29]$ and topoisomerase II [30]. The results obtained in this study indicate that other tests should be considered in perspective for the tested compounds (Q and Q5), considering in silico tests for the investigation of targets that may be involved in the observed death mechanisms.

\subsection{Anti-Inflammatory and Cytotoxicity Activities}

Then, we focused on evaluating the biological activity of the novel derivative. First, non-toxic concentrations of $\mathrm{Q}$ and Q5 were determined in peritoneal macrophages obtained from BALB/c mice. The $\mathrm{CC}_{50}$ values did not demonstrate cytotoxicity at concentrations equal to or less than $80 \mu \mathrm{M}$ (Figure 2A,D). Dexamethasone was not cytotoxic at the concentration tested $(20 \mu \mathrm{M})$. Based on this, subsequent tests were carried out at concentrations not exceeding $80 \mu \mathrm{M}$.

The immunomodulatory activity of $\mathrm{Q}$ and Q5 was investigated to determine the effects of compounds on proinflammatory mediator secretion. The immunomodulatory effects of the compounds $(\mathrm{Q}$ and $\mathrm{Q} 5)$ were initially evaluated in cultures of peritoneal macrophages through the production of nitric oxide. As expected, macrophage activation with LPS PLUS IFN $\gamma$ increased the amount of nitrite production (Figure 2B,E). Treatment with quercetin inhibited, in a concentration-dependent manner, the production of nitrite $(p<0.05)$.

The pentaacetyl compound (Q5) did not demonstrate similar activity at $20 \mu \mathrm{M}$. Interestingly, the activity was significant at the highest concentrations tested (40 and $80 \mu \mathrm{M})$, for both compounds. At the highest concentration tested $(80 \mu \mathrm{M})$, the effects of the compounds were similar to those observed in cultures of activated macrophages and treated with $20 \mu \mathrm{M}$ dexamethasone. The compounds were not cytotoxic for peritoneal macrophages at the tested concentrations $(20,40$ and $80 \mu \mathrm{M})$. 
A

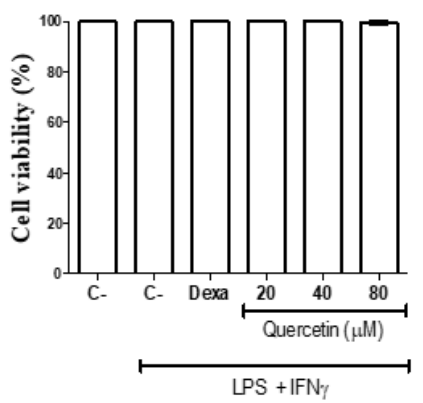

D

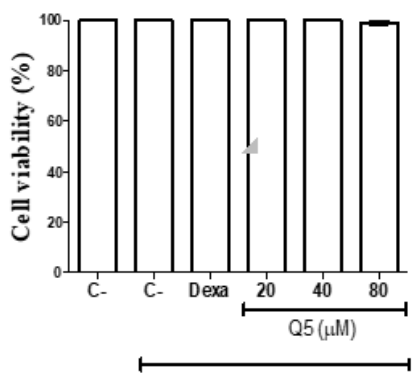

B

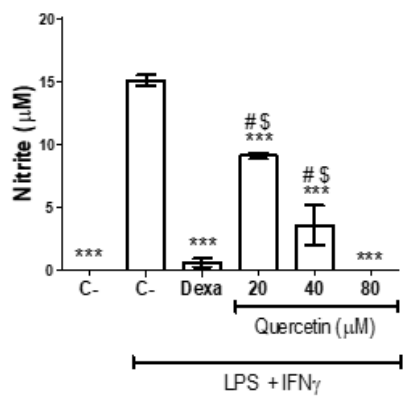

$\mathbf{E}$

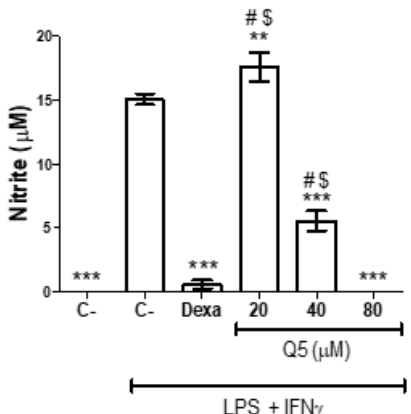

C

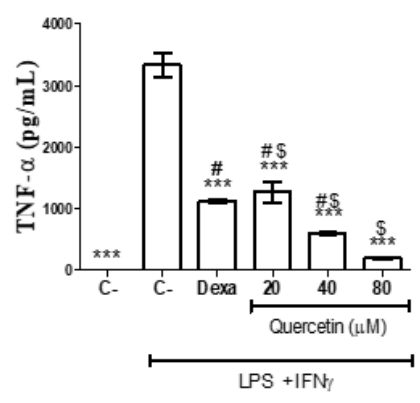

F

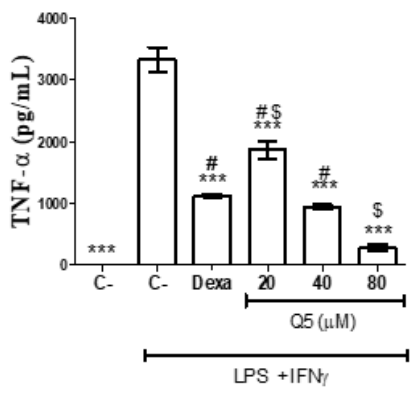

Figure 2. Effects of quercetin (Q) and quercetin-penta acetate analogue (Q5) on macrophages (in vitro). Peritoneal exudate macrophages stimulated or not with LPS + INF $\gamma$ were cultured in the presence or absence of compounds $(20,40$ or $80 \mu \mathrm{M})$ or dexamethasone $(20 \mu \mathrm{M})$. Cell viability was determined by the Alamar Blue method (A,D). Cell supernatant was collected after $24 \mathrm{~h}$ for nitrite quantification (B,E) or $4 \mathrm{~h}$ for TNF measurement (C,F). C- Group of untreated and unstimulated cells. C- Group of cells stimulated with LPS + INF $\gamma$. Values are represented by the mean \pm standard deviation of the mean of nine determinations obtained from three independent experiments. ${ }^{* * *} p<0.001$ compared to stimulated and untreated cells, ${ }^{* *} p<0.01$ compared to stimulated and untreated cells, $\# p<0.05$ compared to unstimulated and untreated cells and $\$ p<0.05$ compared to cells treated with dexamethasone.

For a better characterization of the anti-inflammatory effect of the compounds $(\mathrm{Q}$ and Q5), the inflammatory cytokine TNF was quantified by the Enzyme Linked ImmunoSorbent Assay (ELISA) method. Macrophage stimulation using LPS + INF-y induced a prominent increase in TNF production. Treatment with $\mathrm{Q}$ and Q5 significantly reduced the production of TNF $(p<0.05)$ in a concentration-dependent manner (Figure $2 \mathrm{C}, \mathrm{F}$ ).

The reduction of inflammatory factors by quercetin is diversely described, including modulation for Th-2 inflammatory profiles, related to protection in neural diseases [31,32]. The anti-inflammatory action of quercetin is well described in the literature [33,34]. However, there are few studies that demonstrate the anti-inflammatory potential of the Q5 analogue. This study corroborates the findings of Chen et al. [35], who evidenced the role of Q and Q5 in the inhibition of the NO production induced by LPS, in a concentrationdependent manner without deleterious cytotoxic effects for the RAW 264.7 macrophage lineage. Furthermore, this study demonstrated the unprecedented effect of Q5 in inhibiting the pro-inflammatory cytokine TNF.

The data obtained indicate the conservation of the effects on the semi-synthetic molecule (Q5); however, the dosage of other factors, such as the cytokine IL-10, can be a perspective in the evaluation of these profiles. Therefore, Q5 can be considered a potential molecule for future in vitro and in vivo tests aiming at an additional therapeutic alternative with anti-inflammatory activity.

The cytotoxicity of the tested compounds (Q and Q5) was evaluated at 20, 40 and $80 \mu \mathrm{M}$ using the AlamarBlue colorimetric method in a healthy cell line (MRC-5, human lung 
fibroblasts) and in two different cancer cell lines, HepG2 (human hepatocellular carcinoma) and HL-60 (human promyelocytic leukemia), as shown in Figure 3. Doxorubicin was the standard drug used as a positive control.

A

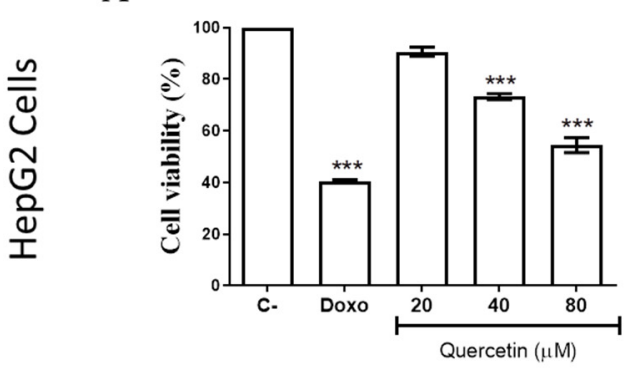

$\mathrm{C}$

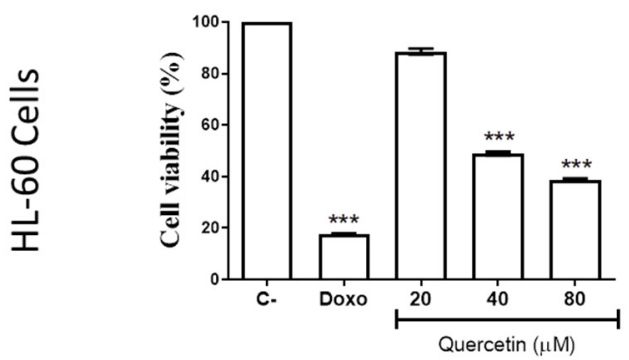

$\mathrm{B}$

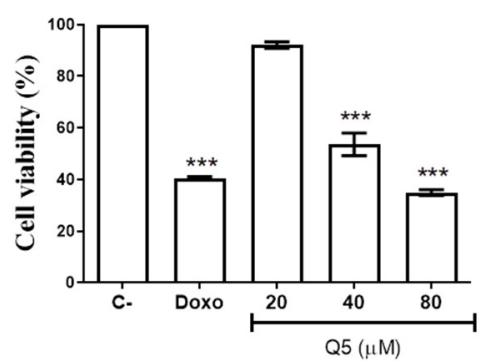

$\mathrm{D}$

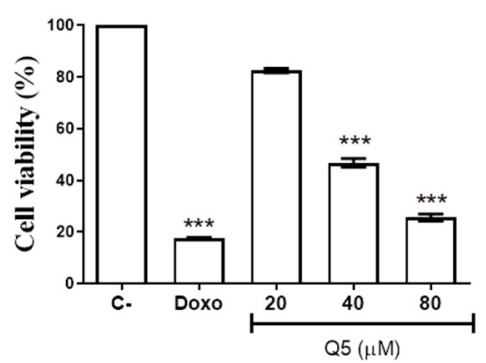

Figure 3. Effects of quercetin $(\mathrm{Q})$ and the quercetin-pentaacetate analogue (Q5) on the viability of HepG2 $(\mathbf{A}, \mathbf{B})$ and HL-60 $(\mathbf{C}, \mathbf{D})$ cells $(20,40$ and $80 \mu \mathrm{M})$ or doxorubicin $(5 \mu \mathrm{M})$ as determined by AlamarBlue after $72 \mathrm{~h}$ of treatment. Values are represented as the mean $\pm \mathrm{SD}$ of three independent experiments performed in triplicate. ${ }^{* * *} p<0.001$ compared to untreated cells.

As shown in Figure 3, for HepG2 cells, quercetin (Q) did not show significant cytotoxic activity at the highest concentration investigated $(80 \mu \mathrm{M})$, and its pentaacetate analogue (Q5) showed reduced activity $\left(\mathrm{IC}_{50}=53.9 \mu \mathrm{M}\right)$. For the HL-60 cancer cell line, quercetin was shown to be not very active $\left(\mathrm{IC}_{50}=51.3 \mu \mathrm{M}\right)$; however, interestingly, $\mathrm{Q} 5$ was significantly more active than quercetin with an $\mathrm{IC}_{50}$ of $33.6 \mu \mathrm{M}$. The standard drug doxorubicin had $\mathrm{IC}_{50}$ values ranging from 0.1 to $0.2 \mu \mathrm{M}$ for cancer cell lines showing significant cytotoxic effects against the healthy cell line MRC-5 (Table 1), which was not seen for the compounds (Q and Q5).

Table 1. Cytotoxicity of the compounds Quercetin $(\mathrm{Q})$ and Quercetin penta-acetate (Q5) against the healthy cell line MRC-5 (human lung fibroblasts) and different cancer cell lines: HepG2 (human hepatocellular carcinoma), HL-60 (human promyelocytic leukemia) and C6 (rat glioma).

\begin{tabular}{cccc}
\hline & \multicolumn{3}{c}{ Tested Compounds $\left(\mathrm{IC}_{\mathbf{5 0}} \boldsymbol{\mu M}\right)$} \\
\cline { 2 - 4 } & Quercetin $(\mathbf{Q})$ & Q5 & Doxorrubicin \\
\hline Cancer cells & & & \\
$\mathrm{IC}_{50}(\mu \mathrm{M})^{\mathrm{a}}$ HL-60 & $51.3( \pm 0.4)$ & $33.6( \pm 2.6)$ & $0.2( \pm 0.0)$ \\
$\mathrm{IC}_{50}(\mu \mathrm{M})^{\mathrm{b}}$ HepG2 & $>80$ & $53.9( \pm 11.3)$ & $0.1( \pm 0.0)$ \\
Non-cancer cells & & & $0.9( \pm 0.0)$ \\
CC $_{50}$ MRC-5 & $>80$ & $>80$ & \\
\hline
\end{tabular}

a Determined in HL-60 incubated with compounds for $72 \mathrm{~h}^{\mathrm{b}}{ }^{\mathrm{b}}$ determined in HepG2 incubated with compounds for $72 \mathrm{~h}$. Values represented as the mean $\pm \mathrm{SD}$ and were calculated using three independent experiments. $\mathrm{CC}_{50}=50 \%$ cytotoxic concentration. $\mathrm{IC}_{50}=50 \%$ inhibitory concentration.

For the HL-60 cell line, the $\mathrm{Q}$ and $\mathrm{Q} 5$ presented values of 51.3 and $33.6 \mu \mathrm{M}$, respectively, in agreement with Massi et al. [17]. Regarding cytotoxicity in non-tumor cells, $Q$ and Q5 presented IC50 values $>80 \mu \mathrm{M}$, showing a selective profile against the cancer cell line. Few studies have demonstrated the activity of the quercetin Q5 analogue in cancer cell 
lines. However, Q5 activity in a HeLa tumor cell lineage was documented by Danihelová et al. [22], which showed that acetylated esters of quercetin were the most effective cytotoxic derivatives. No data were found on the cytotoxic role of Q5 in HepG2 lineage cells. Only one study was found in the literature revealing that the tetra-acetylated analogue of quercetin had a significant effect on the inhibition of HL-60 lineage cells through the activation of caspase-3, promoting apoptosis [36].

A colorimetric method MTT assay was used to access the cytotoxicity in C6 cell culture. Quercetin and Q5 induced a decrease in $570 \mathrm{~nm}$ MTT absorbance that represents mitochondrial dehydrogenase activity and suggests a decrease in the cell viability in C6 cells. As reveled in Figure 4, quercetin-induced cytotoxicity in C6 cells in concentrations higher than $25 \mu \mathrm{M}$ for $72 \mathrm{~h}$ (Figure $4 \mathrm{~A}$ ), while $0.78 \mu \mathrm{M}$ of $\mathrm{Q} 5$ for $72 \mathrm{~h}$ was able to decrease cell viability (Figure 4B). It was observed that $50 \mu \mathrm{M}$ quercetin (Q) and Q5 decreased the cell viability to $41.3 \% \pm 2.9 \%$ and $47.5 \% \pm 1.2 \%$, respectively, when compared with the control group $(100.0 \% \pm 6.4 \%)$ (Figure $4 \mathrm{~A}, \mathrm{~B})$. No significant changes in cell viability were visualized in $\mathrm{C} 6$ cultures treated with DMSO $(0.05 \%)$, when compared with untreated cells.

A

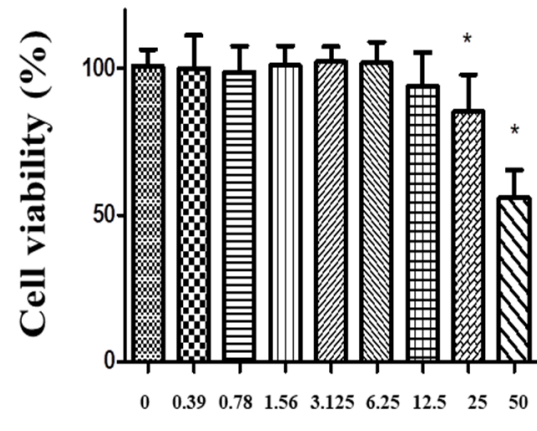

$Q[\mu \mathrm{M}]$

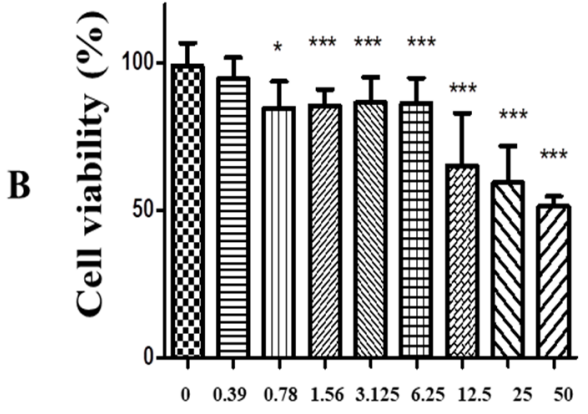

Q5 $[\mu \mathrm{M}]$

Figure 4. Analysis of cytotoxic activity by MTT test in C6 cells exposed to Q and Q5 compound at concentrations of $50 \mu \mathrm{M}$ and 7 1:2 dilutions. (A) C6 after $72 \mathrm{~h}$ of exposure to quercetin. (B) C6 after $72 \mathrm{~h}$ of exposure to quercetin pentaacetate (Q5). Cells under control conditions were treated with $0.05 \% \mathrm{DMSO}-\mathrm{a}$ vehicle for drug dilution. The results expressed as a percentage in relation to the control, taken as $100 \%\left({ }^{*} p<0.05 ;{ }^{* * *} p<0.001\right)$. The different patterns of the column chart represent different concentrations of quercetin $(\mathrm{Q})$ in $(\mathbf{A})$, and quercetin pentaacetate (Q5) in (B).

Based on the results obtained, we then investigated the morphological effects of compounds Q and Q5 $(50 \mu \mathrm{M})$ on the C6 cells, at 24, 48 and $72 \mathrm{~h}$ of the treatment, using optical microscopy. Quercetin pentaacetate (Q5) at $50 \mu \mathrm{M}$ induced changes in the morphology of C6 glioma cells within the first $24 \mathrm{~h}$, with a visible reduction in cytoplasmic prolongations when compared to the control group (Figure 5). After $48 \mathrm{~h}$ of treatment with Q5, the cells assumed a rounded morphology characterized by retraction of the cell body and shapeless membrane (which was not reported in the scientific literature), unlike quercetin, which, during this time of treatment, presented a morphological aspect similar to fibroblasts [37]. Any other morphological changes were visualized in cells under other treatment conditions. 
DMSO (0.05\%)

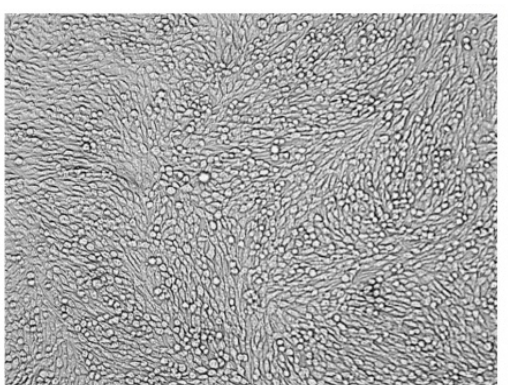

Quercetin (Q)

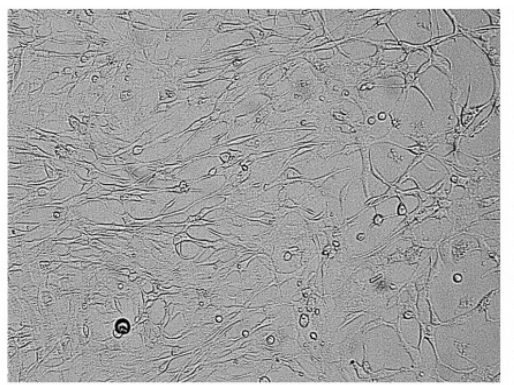

$24 h$

$48 h$
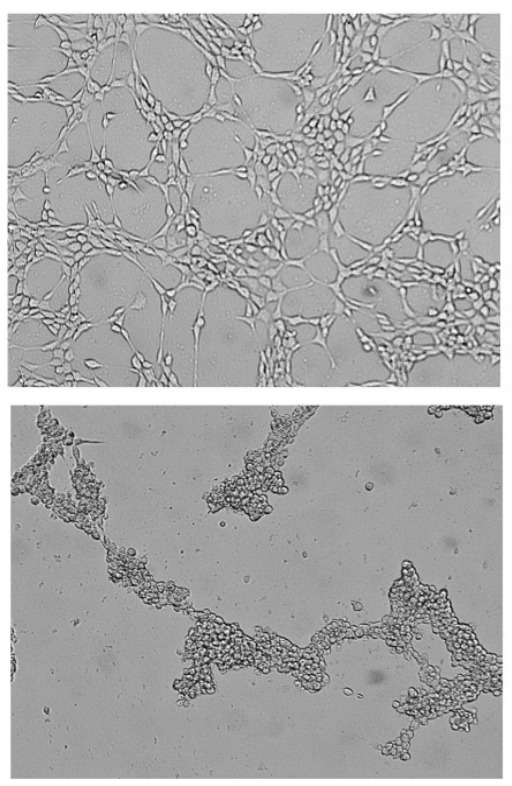

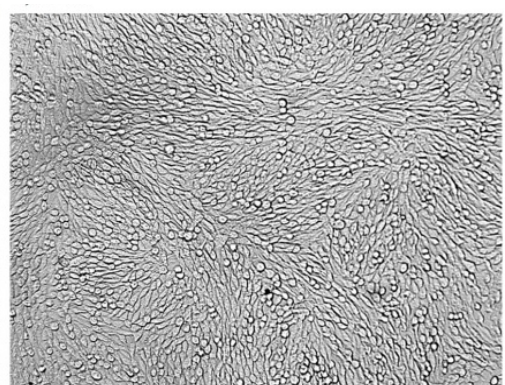

Quercetin pentaacetate (Q5)
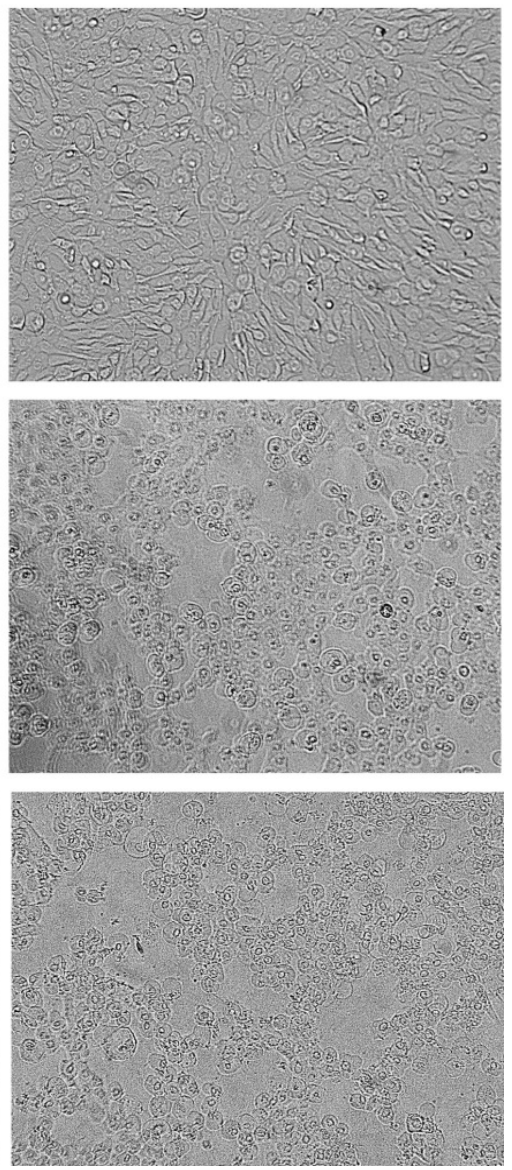

Figure 5. Morphological changes of C6 cells under control conditions (0.05\% DMSO), after 24, 48 and $72 \mathrm{~h}$ of exposure to $50 \mu \mathrm{M}$ of quercetin $(\mathrm{Q})$ or quercetin-pentaacetate (Q50) compounds.

The hydroxyl substitution by the acetyl groups may promote improved cellular absorption of the quercetin analogues favoring various biological tests, particularly in cancer cells [38,39]. Bispo da Silva et al. [40] demonstrated, by treating C6 cells with the flavonoids rutin and quercetin, a significant reduction in the proportion of adherent $\mathrm{C} 6$ cells, with a thinner and bipolar morphological phenotype, compared to control cultures. Treatment of $\mathrm{C} 6$ cells with flavonoids inhibited the migratory properties of viable C6 cells after $24 \mathrm{~h}$ of treatment. In control conditions, microglia presented a rounder phenotype; after rutin treatment, more than $50 \%$ of cells acquired a branched, multipolar phenotype, and the others acquired the amoeboid phenotype, both indicating activation.

Studies indicate that quercetin interferes in the regulation of cell signaling transduction pathways associated with cell death by apoptosis and in the stages of cell cycle progression [41,42]. Santos et al. [14] indicated a potential reduction in the growth of 
GL-15 human glioblastoma cells. Bi et al. [43] visualized an induction of autophagy of U87 and U251 human glioblastoma cells in a dose-dependent manner.

The results obtained corroborate with Danihelova et al. [22], in which the acetyl groups inserted in the quercetin molecule promoted an improvement in anticancer activity. Furthermore, they indicated a greater tropism for cancer cells, particularly for cells of neural lineages. This study is unprecedented in relation to the Q5 analogue in the treatment of C6 glioma cells. Dell'Albani et al. [44] showed a better action of acyl derivatives of quercetin in cultures of human glioma strains U373-MG and murine glioma 9L, indicating pathways of death by apoptosis. The modification of cell morphology to a rounded profile can refer to death mechanisms, such as apoptosis, widely attributed to quercetin [45-47]. In future perspectives, tests with healthy neural cells may help to elucidate this hypothesis.

\section{Materials and Methods}

\subsection{Reagents and Materials}

All reagents (quercetin, pyridine, acetic anhydride, tricoloroisocyanuric acid, dichloro methane, 2,4-dinitro-phenylhydrazine, hydroxylamine hydrochloride, sodium acetate, petroleum ether, sulfuric acid, potassium persulfate and nitrate) were analytical grade and commercially available (Quimex ${ }^{\circledR}$, Merck, Brazil and Sigma Aldrich ${ }^{\circledR}$, St. Louis, MO, USA). For the preparation of all standard solutions and samples, ultrapure water (with

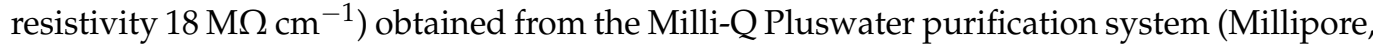
Molsheim, France) was used. All laboratory glassware was washed in a $10 \%(v / v) \mathrm{HNO}_{3}$ solution for $24 \mathrm{~h}$, rinsed with high-purity water and dried at ambient temperature.

\subsection{Synthesis and Characterization}

The structural analog was obtained after quercetin molecular modification from the more accessible and reproducible synthetic route (penta acetylation). We applied the green chemistry principles with minimization of substance use. The pentaacetyl analog (Q5) was obtained after the molecular modification of quercetin, from a synthetic route, which uses acetic anhydride as an acylating agent and pyridine as a catalyst.

The mixture containing quercetin ( $300 \mathrm{mg}, 1$ eq.), acetic anhydride $(0.80 \mathrm{~mL}, 20$ eq.) and pyridine $(7.5 \mathrm{~mL})$ was kept under magnetic stirring at room temperature. After $24 \mathrm{~h}$ of stirring, $250 \mathrm{~mL}$ of dichloromethane was added to the reaction medium. Then, the reaction was washed with $10 \% \mathrm{HCl}(3 \times 100 \mathrm{~mL})$, diluted $\mathrm{NaOH}(3 \times 50 \mathrm{~mL})$ and water $(3 \times 100 \mathrm{~mL})$; dried over anhydrous sodium sulfate; filtered; and evaporated, in the rotary evaporator (Fisatom, Minas Gerais, Brazil) [21]. The amount of Q5 and the yield obtained were $280 \mathrm{mg}$ and $54 \%$, respectively.

The structural modification reaction of the quercetin molecule was monitored by thin layer chromatography (TLC) using a mixture of hexane and ethyl acetate (1:1) as solvents. For the physicochemical characterization, the melting point was used. Fourier Transform Infrared (FTIR) tests by the Attenuated Total Reflection (ATR) method were performed by a FTIR Spectrum 100S model (Perkin Elmer, Waltham, MA, USA), with the acquisition of the scanning spectra in the mid-infrared (4000 to $600 \mathrm{~cm}^{-1}$ ).

The sample (mass $\sim 5.0 \mathrm{mg}$ ) was placed on the ATR crystal and subjected to a pressure of approximately $20 \mathrm{~N}$ with the aid of a manual mechanical press. FTIR spectra were traced by OriginPro8 software, OriginLAB ${ }^{\circledR}$ (www.originlab.com, accessed in 10 September 2021). Nuclear Magnetic Resonance (NMR) spectra were recorded in a Bruker Avance III $500 \mathrm{MHz}$ (Uster, Switzerland) spectrometer-500 MHz for ${ }^{1} \mathrm{H}$ NMR and $125 \mathrm{MHz}$ for ${ }^{13} \mathrm{C}$ NMR, using DMSO as a solvent. Chemical shifts were expressed in the ppm scale $(\mu \mathrm{g} / \mathrm{mL})$, and chloroform $\left(\mathrm{CHCl}_{3}\right)$ was used as the internal reference.

NMR spectra were processed by TopSpin ${ }^{\circledR} 4.0$ software (Bruker Biospin, Coventry, UK) and compared with literature data [38]. The NMR data were: ${ }^{1} \mathrm{H}$ NMR (500 MHz, $\left.\mathrm{CDCl}_{3}\right) 2.34\left(6 \mathrm{H}, \mathrm{s},-\mathrm{OCOCH}_{3}\right) ; 2.35\left(3 \mathrm{H}, \mathrm{s},-\mathrm{OCOCH}_{3}\right) ; 2.35\left(3 \mathrm{H}, \mathrm{s},-\mathrm{OCOCH}_{3}\right) ; 2.44(3 \mathrm{H}$, $\left.\mathrm{s},-\mathrm{OCOCH}_{3}\right) ; 6.88(1 \mathrm{H}, \mathrm{d}, J=2.5 \mathrm{~Hz}) ; 7.34(1 \mathrm{H}, \mathrm{d}, J=2.0 \mathrm{~Hz}) ; 7.36(1 \mathrm{H}, \mathrm{d}, J=8.5) ; 7.70$ $(1 \mathrm{H} \mathrm{d}, J=2.0 \mathrm{~Hz}) ; 7.73\left(1 \mathrm{H}, \mathrm{dd}, J_{1}=8.5 \mathrm{~Hz}, J_{2}=2.0 \mathrm{~Hz}\right) ;{ }^{13} \mathrm{C} \mathrm{NMR}\left(125 \mathrm{MHz}, \mathrm{CDCl}_{3}\right) \delta$ 
$170.04 ; 169.24 ; 167.86 ; 167.79 ; 156.87 ; 154.28 ; 150.43 ; 144.40 ; 142.22 ; 127.78 ; 126.42 ; 124.01$; $123.93 ; 123.85 ; 113.89 ; 108.96 ; 21.16 ; 21.02 ; 20.65 ;$ and 20.49 .

\subsection{Antioxidant $A B T S^{\bullet+}$ Radical Activity}

The $\mathrm{ABTS}^{\bullet+}$ sequestration activity was adapted from the method described by Dorman and Hiltunen [48]. Potassium persulfate and ABTS (Sigma Aldrich ${ }^{\circledR}$, St. Louis, MO) were dissolved in distilled water to form a final concentration of $2.45 \mathrm{mM}$ and $7 \mathrm{mM}$, respectively. The $\mathrm{ABTS}^{\bullet+}$ solution was produced by adding both solutions at a rate of $1: 1$, and then the solution was incubated at room temperature for $16 \mathrm{~h}$ in the dark.

The resulting solution, intensely colored, was adjusted with ethanol, in the spectrophotometer, to an absorbance of $0.7 \pm 0.05 \mathrm{~nm}$ at $734 \mathrm{~nm}$ before use. We used $30 \mu \mathrm{L}$ of the samples, or Trolox (Sigma Aldrich ${ }^{\circledR}$, St. Louis, MO), as a reference standard at different concentrations $(5,10,25,50,75$ and $100 \mu \mathrm{M})$, were added to $3 \mathrm{~mL}$ of the $\mathrm{ABTS}^{\bullet+}$ solution and awaited to reacts for $6 \mathrm{~min}$. The absorbance was measured at $734 \mathrm{~nm}$ against a blank (ethanol). The $\mathrm{ABTS}^{\bullet+}$ scavenging capacity was calculated as:

$$
\mathrm{ABTS}^{\bullet+} \text { scavenging effect }(\%)=(1-\mathrm{A} 0 / \mathrm{A} 1) \times 100 \text {; }
$$

where A0 is the absorbance of the control, and A1 is the absorbance of the sample or standard. All determinations were performed in triplicate. $\mathrm{IC}_{50}$ values were calculated and expressed as the mean \pm SD in $\mu \mathrm{M}$.

\subsection{Antileishmania Activity}

L. amazonensis (MHOM/BR88/BA-125 Leila strain) and L. braziliensis (MHOM/BR88/BA3456) promastigotes $\left(1 \times 10^{6}\right.$ per well) were cultured in a 96-well plate in Schneider medium (Sigma-Aldrich ${ }^{\circledR}$, St. Louis, MO, USA) supplemented with $10 \%$ fetal bovine serum (FBS; GIBCO) and $50 \mu \mathrm{g} \mathrm{mL}^{-1}$ gentamicin (Life, Carlsbad, CA, USA) and subjected to treatment with different concentrations (100 $\mu \mathrm{M}$; six dilutions 1:2) of Q5. The parasites were incubated for $72 \mathrm{~h}$ at $26^{\circ} \mathrm{C}$. Then, $20 \mu \mathrm{L} /$ well of AlamarBlue (Invitrogen, Carlsbad, CA, USA) was added over $2 \mathrm{~h}$. The reading was carried out in a spectrophotometer using the wavelengths of 570 and $600 \mathrm{~nm}$. The calculation of axenic culture inhibition was determined based on the untreated control [49].

\subsection{Anti-Inflammatory and Cytotoxicity Activities \\ 3.5.1. Drugs}

Dexamethasone (Sigma-Aldrich ${ }^{\circledR}$, St. Louis, MO, USA), a synthetic glucocorticoid, was used as positive control in immunomodulatory assays. Doxorubicin (doxorubicin hydrochloride, Laboratory IMA S.A.I.C., Buenos Aires, Argentina) was used as a reference anticancer drug. All compounds were dissolved in dimethyl sulfoxide (DMSO; PanReac, Barcelona, Spain) and diluted in cell culture medium for use in the assays. The final concentration of DMSO was less than $1 \%$ in all experiments.

\subsubsection{Animals}

BALB/c mice, aged 4-10 weeks, were provided by the vivarium of Gonçalo Moniz Institute/FIOCRUZ-BA (IGM, Salvador, Bahia, Brazil) where they were kept in cages containing a maximum of five mice. All cages were kept in an acclimatized room at $21^{\circ} \mathrm{C} \pm 1{ }^{\circ} \mathrm{C}$, on a 12-h light/dark cycle, with water and food ad libitum throughout the experimental period. The experiments with animals were approved by the Ethics and Animal Use Committee of Gonçalo Moniz/FIOCRUZ-BA Institute (IGM-018/15).

\subsubsection{Cells}

HL-60 (human acute promyelocytic leukemia) and HepG2 (human hepatocellular carcinoma) were obtained from the American Type Culture Collection-ATCC (Rocville, ML, USA), were used. To assess the selectivity of quercetin (Q) and the Q5 derivative on the proliferation of non-cancer cells, the MRC-5 lineage (human lung fibroblast), also obtained 
from ATCC, was used. Cell lines were grown in cell culture bottles $\left(75 \mathrm{~cm}^{3}, 250 \mathrm{~mL}\right.$ volume $)$ using RPMI 1640 culture medium $\left(\mathrm{Gibco}^{\mathrm{TM}}\right)$ supplemented with $10 \%$ fetal bovine serum $\left(\mathrm{Gibco}^{\mathrm{TM}}\right)$ and $50 \mu \mathrm{g} / \mathrm{mL}$ gentamicin $\left(\mathrm{Gibco}^{\mathrm{TM}}\right)$. The cells were kept in incubators with an atmosphere of $5 \% \mathrm{CO}_{2}$ at $37{ }^{\circ} \mathrm{C}$ and monitored daily. All cell lines were tested for mycoplasma using a Hoechst staining mycoplasma detection kit (Sigma-Aldrich, St. Louis, MO, USA).

C6 cell line was derived from rat glial tumors induced by $n$-nitrosomethylurea [50]. This glioma cells were cultured as described by de Oliveira et al. [51]. The cells were incubated at $37^{\circ} \mathrm{C}$ in a humidified incubator at $5 \% \mathrm{CO}_{2}$. C6 cells were grown on cell culture dishes (100-mm Ø, TPP) in DMEM medium supplemented with $100 \mathrm{UI} / \mathrm{mL}$ penicillin G, $100 \mu \mathrm{g} / \mathrm{mL}$ streptomycin, $7 \mathrm{mM}$ glucose, $2 \mathrm{mM}$ L-glutamine, $1 \mathrm{mM}$ pyruvate and $10 \%$ fetal calf serum. The culture medium was changed every 2 days. Twenty-four hours prior to treatments, C6 cells were seeded in Petri dishes of $35 \mathrm{~mm}$ in diameter or 96-well plates at a density of $3.5 \times 10^{4}$ cells/well.

All cell lines were tested for mycoplasma using the Mycoplasma Stain Kit (SigmaAldrich) to validate the use of cells free from contamination. The cell lines information is contained in the database "Cell Bank of Rio de Janeiro (BCRJ)": HepG2 cell (Code: 0291), HL-60 cell (Code: 0104) and C6 cell (Code: 0057).

\subsubsection{Cytotoxic Activity Assay}

To assess the cytotoxicity of the tested compounds (Q and Q5) on the HL-60 (human acute promyelocytic leukemia) and HepG2 cells, the colorimetric method of Alamar Blue (Invitrogen, Carlsbad, CA, USA) was used. Alamar Blue (resazurin) is an indicator that produces a colorimetric change and a fluorescent signal in response to metabolic activity. Resazurin is reduced to resorufin by metabolically active cells. The oxidized form is blue (non-fluorescent/non-viable cell), and the reduced form is pink (fluorescent/viable cell). The reduction of resazurin to resorufin reflects the cell viability [52].

In the assay, cells were distributed in 96-well plates at a predefined density of $0.3 \times 10^{6}$ cells $/ \mathrm{mL}$ for cells of the HL-60 lineage and $0.7 \times 10^{5}$ cells $/ \mathrm{mL}$ for cells of the HepG2 lineage. The compounds were added in a series of eight concentrations (80 to $0.62 \mu \mathrm{M})$, with the exception of doxorubicin, which was used in concentrations ranging from 0.003 to $5 \mu \mathrm{M}$. The negative control received the same amount of DMSO $(0.025 \%)$. The plates were incubated for $72 \mathrm{~h}$ in an oven at $37^{\circ} \mathrm{C}$ and $5 \% \mathrm{CO}_{2}$. After this period, $20 \mu \mathrm{L} /$ well of Alamar Blue was added, and the plates were incubated for another $4 \mathrm{~h}$. The plates were read using a spectrophotometer (Spectramax 190, Molecular Devices, Sunnyvale, CA, USA), at wavelengths of 570 and $600 \mathrm{~nm}$.

The C6 cell viability was determined using the colorimetric method described by Hansen et al. [53]. The MTT (3-4,5-dimethylthiazol-2-yl, 2,5-diphenyltetrazolium bromide) was dissolved at a concentration of $5 \mathrm{mg} / \mathrm{mL}$ in sterile phosphate buffered saline (PBS) at room temperature, and the solution was further sterilized by passing through a $0.2-\mathrm{mm}$ filter and stored at $4{ }^{\circ} \mathrm{C}$ in the dark. In the assay, cells were distributed in 96 -well plates at a predefined density of $3.5 \times 10^{4}$ cells $/ \mathrm{mL}$ for the $\mathrm{C} 6$ cell lineage. The compounds were added in a series of eight concentrations ( 80 to $0.39 \mu \mathrm{M})$.

MTT was added in each well at a final concentration of $2 \mathrm{mg} / \mathrm{mL}$, and the cells were incubated for $2 \mathrm{~h}$. After that, cells were lysed with $20 \%(w / v)$ sodium dodecyl sulfate (SDS) and $50 \%(v / v)$ dimethylformamide (DMF) solution ( $\mathrm{pH} 4.7)$, in an overnight incubation at room temperature $[54,55]$. The absorbance was measured with a spectrophotometer microplate reader $(570 \mathrm{~nm})$, Thermo Scientific ${ }^{\circledR}$ Flash Varioskan (Version 3001, Thermo Fisher Scientific, Vantaa, Finland). Eight replicates were used for each concentration. Cell viability was expressed as the percentage of absorbance at $570 \mathrm{~nm}$, and the control was adopted as $100 \%$. After treatments, cell morphology was evaluated by light microscopy using an optic microscope (Eclipse TS100 inverted microscope, Nikon Instruments, Tokyo, Japan) and photographed using a digital camera (Coolpix S4300, Nikon Instruments, Tokyo, Japan). 


\subsubsection{Macrophage Culture}

Peritoneal exudate macrophages $\left(2 \times 10^{5}\right.$ cells /well) were incubated in 96-well plates in DMEM medium supplemented with $10 \%$ PBS and $50 \mu \mathrm{g} / \mathrm{mL}$ gentamicin, in triplicate, stimulated or not with LPS $(500 \mathrm{ng} / \mathrm{mL})$ and IFN- $\gamma(5 \mathrm{ng} / \mathrm{mL})$ and treated or not with different concentrations of compounds $(20,40$ and $80 \mu \mathrm{M})$. The cells were kept in an incubator at $37^{\circ} \mathrm{C}$ and $5 \% \mathrm{CO}_{2}$ for 4 and $24 \mathrm{~h}$. After this period, the culture supernatants were collected for cytokines and nitric oxide dosage. In some assays, to assess the cytotoxicity, the supernatant was replaced with medium plus 10\% Alamar Blue (Invitrogen, Carlsbad, CA, USA), and the plates were incubated for an additional $4 \mathrm{~h}$. The spectrophotometer reading was performed at 570 and $600 \mathrm{~nm}$.

\subsubsection{TNF Dosage}

TNF measurement was performed from cell culture supernatants, using the sandwich ELISA technique, using Development System kitsDuoset ELISA (R\&D Systems, Minneapolis, MI, USA), according to the manufacturer's recommendations. ELISA plates (NUNC-IMMUNO PLATE Maxisorp Surface) were sensitized with $50 \mu \mathrm{L} /$ well of the capture antibody, at a concentration of $2 \mu \mathrm{g} / \mathrm{mL}$, diluted in PBS $1 \mathrm{x}$ and incubated for $16 \mathrm{~h}$ at $4{ }^{\circ} \mathrm{C}$. The plates were washed three times with $1 \times$ PBS $/ 0.05 \%$ tween 20 and blocked with $100 \mu \mathrm{L} /$ well of $1 \times$ PBS and $0.05 \%$ tween 20 and $0.1 \%$ bovine albumin for $2 \mathrm{~h}$.

Then, $50 \mu \mathrm{L} /$ well of samples, blank and standard curve of recombinants diluted in Tris-saline buffer $(20 \mathrm{mM}$ trix in the base and $150 \mathrm{mM} \mathrm{NaCl})$ containing $0.1 \%$ bovine albumin and 0.05 were added \% tween 20 for $2 \mathrm{~h}$ at room temperature. The standard was serially diluted (1:2), from the initial concentration of $2000 \mathrm{pg} / \mathrm{mL}$, with 11 duplicate dilutions. The plate was washed three times with PBS $/ 0.05 \%$ tween and incubated with $50 \mu \mathrm{L}$ of the detection antibody (biotinylated) at a concentration of $400 \mathrm{ng} / \mathrm{mL}$ for a period of $2 \mathrm{~h}$.

The plate was washed three times with PBS/0.05\% tween and incubated for $20 \mathrm{~min}$ with avidin-peroxidase diluted 1:200. The development was carried out by adding TMB substrate (Thermo Fisher) and interrupted with $0.05 \mathrm{M}$ phosphoric acid. The reading of the reaction was determined using a spectrophotometer (Spectramax) (Molecular Devices, San Jose, CA, USA), with a $450 \mathrm{~nm}$ filter. Analyses were performed using the Softmax 4.3.1 Software (Molecular Devices, San Jose, CA, USA).

\subsubsection{Nitric Oxide Dosage}

The production of nitrite in macrophage supernatants was estimated through the quantification of its oxidative product, nitrite, by the Griess method [50]. The absorbance was determined in a spectrophotometer (Spectramax) (Molecular Devices, San Jose, CA, USA), with a $570 \mathrm{~nm}$ filter. Analyses were performed using Softmax Software 4.3.1 (Molecular Devices, San Jose, CA, USA), and the results were expressed in $\mu \mathrm{M}$ of nitrite, based on a standard curve of sodium nitrite with an initial concentration of $400 \mu \mathrm{M}$.

\subsection{Statistical Analysis}

The one-way ANOVA test followed by the Bonferroni multiple comparison post-test was used to determine the statistical significance of the comparisons between groups in the studies. The results were considered statistically significant when $p<0.05$. All analyses were performed using the GraphPad Prism version 5.01 program (GraphPad Software, San Diego, CA, USA).

\section{Conclusions}

The conditions and reactions synthesis media of quercetin analogues showed efficiency in obtaining one compound duly characterized, according to the data described in the literature. The comparative analysis of the antioxidant activity of Q and Q5 showed that quercetin $(\mathrm{Q})$ was more active in scavenging the ABTS ${ }^{\bullet+}$ radical than Q5 $(29 \%$ and $18 \%$, respectively). The reduced antioxidant potential did not demonstrate interference 
in immunomodulatory and antitumoral activities. The chemical modifications proposed in this study enhanced the antiproliferative effect and maintained the anti-inflammatory activity but not cytotoxicity activity in healthy tested cells.

The acetylated derivative (Q5) present improved the cytotoxicity in cancer hepatocellular cells (HepG2), promyelocytic leukemia (LH-60) cells and, particularly, in glioma (C6) cells. The rat glioma $\mathrm{C} 6$ cells traded showed a morphological unprecedent pattern of cell death. Q5 at $50 \mu \mathrm{M}$ for $24 \mathrm{~h}$ induced changes in C6 glioma cell morphology characterized by a round body shape (which was not reported in the scientific literature), unlike quercetin, which presented a fibroblast-like morphology.

Further investigations need to be done to better understand the effects of acetylated derivatives of quercetin, particularly in neuronal cells. This study allowed, for the first time, the application of structurally modified quercetin in neural cells for potential neuroprotective effects.

Supplementary Materials: The following are available online. Figures/Analysis by ${ }^{1} \mathrm{H}$ and ${ }^{13} \mathrm{C}$ NMR. Figure S1: Complete ${ }^{1} \mathrm{H}$ NMR spectrum of Quercetin (Q); Figure S2: Expansion of Quercetin (Q) ${ }^{1} \mathrm{H}$ NMR Spectrum; Figure S3: Complete ${ }^{13} \mathrm{C}$ NMR spectrum of Quercetin (Q); Figure S4: Complete ${ }^{1} \mathrm{H}$ NMR spectrum of the obtained compound-Quercetin pentaacetate analogue (Q5); Figure S5: Expansion of the ${ }^{1} \mathrm{H}$ NMR spectrum of the obtained compound-Quercetin pentaacetate analogue (Q5); Figure S6: Expansion of the more aliphatic region of the ${ }^{1} \mathrm{H}$ NMR spectrum of the obtained compound-Quercetin pentaacetate analogue (Q5); Figure S7: Complete ${ }^{13} \mathrm{C}$ NMR spectrum of the obtained compound-Quercetin pentaacetate analogue (Q5); Figure S8: Expansion of the ${ }^{13} \mathrm{C} N M R$ spectrum of the obtained compound-Quercetin pentaacetate analogue (Q5); Figure S9: Expansion of the aliphatic region of the ${ }^{13} \mathrm{C}$ NMR spectrum of the obtained compound-Quercetin pentaacetate analogue (Q5).

Author Contributions: Conceptualization, A.d.F.S.J., L.L.B.d.S., C.S.M. and V.D.A.d.S.; validation, A.d.F.S.J., L.L.B.d.S., C.S.M., M.B.P.S., E.T.G., V.D.A.d.S. and S.L.C.; data curation, A.d.F.S.J., C.S.M. and V.D.A.d.S.; formal analysis, S.V.S.d.S., O.M.B., J.T.S., É.N.S., C.C.d.S., T.B.d.S.M., L.V.P. and I.P.S.; investigation, A.d.F.S.J., L.L.B.d.S., C.S.M., V.D.A.d.S. and S.V.S.d.S.; writing-original draft preparation, A.d.F.S.J., L.L.B.d.S., C.S.M., V.D.A.d.S. and S.V.S.d.S.; writing—review and editing, A.d.F.S.J. and S.V.S.d.S.; visualization and supervision, A.d.F.S.J., L.L.B.d.S., C.S.M. and V.D.A.d.S. All authors have read and agreed to the published version of the manuscript.

Funding: This research received no external funding.

Institutional Review Board Statement: The study was conducted according to the guidelines of the Declaration of Helsinki, and approved by the Ethics and Animal Use Committee of Gonçalo Moniz/FIOCRUZ-BA Institute (IGM-018/15).

Informed Consent Statement: Not applicable.

Data Availability Statement: Not applicable.

Acknowledgments: The authors are grateful for the financial support received (fellowships) from "Coordenação de Aperfeiçoamento de Pessoal de Nível Superior-Brasil (CAPES)", "Fundação de Amparo à Pesquisa do Estado da Bahia (FAPESB)" and "Conselho Nacional de Desenvolvimento Científico e Tecnológico (CNPq)"; for collaborations of the State University of Bahia (UNEB); Gonçalo Moniz Institute, Fiocruz/Bahia; Federal University of Bahia (UFBA) and Research Group: "Biopharmaceutics and Drugs".

Conflicts of Interest: The authors declare no conflict of interest.

Sample Availability: Samples of the compounds are available from the authors.

\section{References}

1. Formica, J.V.; Regelson, W. Review of the biology of quercetin and related bioflavonoids. Food Chem. Toxicol. 1995, 33, 1061-1080. [CrossRef]

2. Materska, M. Quercetin and its derivatives: Chemical structure and bioactivity-A review. Pol. J. Food Nutr. Sci. 2008, 58, 407-413.

3. Wang, T.Y.; Li, Q.; Bi, K.S. Bioactive flavonoids in medicinal plants: Structure, activity and biological fate. Asian J. Pharm. Sci. 2018, 13, 12-23. [CrossRef] [PubMed] 
4. D'Andrea, G. Quercetin: A flavonol with multifaceted therapeutic applications? Fitoterapia 2015, 106, 256-271. [CrossRef]

5. Araújo, M.V.; Queiroz, A.C.; Silva, J.F.M.; Silva, A.E.; Silva, J.K.S.; Silva, G.R.; Silva, E.C.O.; Souza, S.T.; Fonseca, E.J.S.; Camara, C.A.; et al. Flavonoids induce cell death in: Leishmania amazonensis: In vitro characterization by flow cytometry and Raman spectroscopy. Analyst 2019, 144, 5232-5244. [CrossRef] [PubMed]

6. Faixová, D.; Hrčková, G.; Kubašková, T.M.; Mudroňová, D. Antiparasitic effects of selected isoflavones on flatworms. Helminthologia 2021, 58, 1-16. [CrossRef]

7. Manjolin, L.C.; Reis, M.B.G.; Maquiaveli, C.C.; Santos-Filho, O.A.; Silva, E.R. Dietary flavonoids fisetin, luteolin and their derived compounds inhibit arginase, a central enzyme in Leishmania (Leishmania) amazonensis infection. Food Chem. 2013, 141, $2253-2262$. [CrossRef]

8. Tasdemir, D.; Kaiser, M.; Brun, R.; Yardley, V.; Schmidt, T.J.; Tosun, F.; Rüedi1, P. Antitrypanosomal and antileishmanial activities of flavonoids and their analogues: In vitro, in vivo, structure-activity relationship, and quantitative structure-activity relationship studies. Antimicrob. Agents Chemother. 2006, 50, 1352-1364. [CrossRef]

9. Lee, W.J.; Hsiao, M.; Chang, J.L.; Yang, S.F.; Tseng, T.H.; Cheng, C.W.; Chow, J.M.; Lin, K.H.; Lin, Y.W.; Liu, C.C.; et al. Quercetin induces mitochondrial-derived apoptosis via reactive oxygen species-mediated ERK activation in HL-60 leukemia cells and xenograft. Arch. Toxicol. 2015, 89, 1103-1117. [CrossRef]

10. Drummond, E.M.; Harbourne, N.; Marete, E.; Martyn, D.; Jacquier, J.; O’Riordan, D.; Gibney, E.R. Inhibition of proinflammatory biomarkers in THP1 macrophages by polyphenols derived from chamomile, meadowsweet and willow bark. Phytother Res. 2013, 27, 588-594. [CrossRef]

11. Thon, N.; Thorsteinsdottir, J.; Eigenbrod, S.; Schüller, U.; Lutz, J.; Kreth, S.; Belka, C.; Tonn, J.C.; Niyazi, M.; Kreth, F.W. Outcome in unresectable glioblastoma: MGMT promoter methylation makes the difference. J. Neurol. 2016, 264, 350-358. [CrossRef] [PubMed]

12. Perzelova, A.; Tardy, M. Effects of a novel synthetic retinoid on malignant glioma in vitro inhibition of cell proliferation, induction of apoptosis and differentiation. Eur. J. Cancer 2001, 37, 520-530.

13. Wang, G.; Wang, J.; Du, L.; Li, F. Effect and mechanism of total flavonoids extracted from Cotinus coggygria against Glioblastoma cancer in vitro and in vivo. Biomed. Res. Int. 2015, 2015, 856349. [CrossRef] [PubMed]

14. Santos, B.L.; Oliveira, M.N.; Coelho, P.L.C.; Pitanga, B.P.S.; Silva, A.B.; Adelita, T.; Silva, V.D.A.; Costa, M.F.D.; El-Bachá, R.S.; Tardy, M.; et al. Flavonoids suppress human glioblastoma cell growth by inhibiting cell metabolism, migration, and by regulating extracellular matrix proteins and metalloproteinases expression. Chem.-Biol. Interact. 2015, 242, 123-138. [CrossRef] [PubMed]

15. Farhadi, L.; Mohammadi-Motlagh, H.R.; Seyfi, P.; Mostafaie, A. Low concentrations of flavonoid-rich fraction of shallot extract induce delayed-type hypersensitivity and TH1 cytokine IFN $\gamma$ expression in BALB/c mice. Int. J. Mol. Cell. Med. 2014, 3, 16-25.

16. Nair, M.P.N.; Kandaswami, C.; Mahajan, S.; Chadha, K.C.; Chawda, R.; Nair, H.; Kumar, N.; Nair, R.E.; Schwartz, S.A. The flavonoid, quercetin, differentially regulates Th-1 (IFN $\gamma$ ) and Th-2 (IL4) cytokine gene expression by normal peripheral blood mononuclear cells. Biochim. Biophys. Acta 2002, 1593, 29-36. [CrossRef]

17. Massi, A.; Bortolini, O.; Ragno, D.; Bernardi, T.; Sacchetti, G.; Tacchini, M.; De Risi, C. Research progress in the modification of quercetin leading to anticancer agents. Molecules 2017, 22, 1270. [CrossRef]

18. Foti, M.C.; Rocco, C. Unveiling the chemistry behind bromination of quercetin: The "violet chromogen". Tetrahedron Lett. 2014, 55, 1602-1607. [CrossRef]

19. Helgren, T.R.; Sciotti, R.J.; Lee, P.; Duffy, S.; Avery, V.M.; Igbinoba, O.; Akoto, M.; Hagen, T.J. The synthesis, antimalarial activity and CoMFA analysis of novel aminoalkylated quercetin analogs. Bioorg. Med. Chem. Lett. 2015, 25, 327-332. [CrossRef]

20. Özyürek, M.; Akpınar, D.; Bener, M.; Türkkan, B.; Güçlü, K.; Apak, R. Novel oxime based flavanone, naringin-oxime: Synthesis, characterization and screening for antioxidant activity. Chem.-Biol. Interact. 2014, 212, 40-46. [CrossRef]

21. Mattarei, A.; Biasutto, L.; Rastrelli, F.; Garbisa, S.; Marotta, E.; Zoratti, M.; Paradisi, C. Regioselective O-derivatization of quercetin via ester intermediates. An improved synthesis of rhamnetin and development of a new mitochondriotropic derivative. Molecules 2010, 15, 4722-4736. [CrossRef] [PubMed]

22. Danihelová, M.; Veverka, M.; Šturdík, E.; Jantová, S. Antioxidant action and cytotoxicity on HeLa and NIH-3T3 cells of new quercetin derivatives. Interdiscip. Toxicol. 2013, 6, 209-216. [CrossRef] [PubMed]

23. Biasutto, L.; Marotta, E.; De Marchi, U.; Zoratti, M.; Paradisi, C. Ester-based precursors to increase the bioavailability of quercetin. J. Med. Chem. 2007, 50, 241-253. [CrossRef]

24. Mohajeri, M.; Saghaei, L.; Ghanadian, M.; Saberi, S.; Pestechian, N.; Ostadhusseini, E. Synthesis and in vitro leishmanicidal activities of six quercetin derivatives. Adv. Biomed. Res. 2018, 7, 64. [PubMed]

25. Dehghan, G.; Khoshkam, Z. Tin(II)-quercetin complex: Synthesis, spectral characterisation and antioxidant activity. Food Chem. 2012, 131, 422-426. [CrossRef]

26. Oh, W.Y.; Ambigaipalan, P.; Shahidi, F. Quercetin and its ester derivatives inhibit oxidation of food, LDL and DNA. Food Chem. 2021, 364, 130394. [CrossRef]

27. Fonseca-Silva, F.; Inacio, J.D.F.; Canto-Cavalheiro, M.M.; Almeida-Amaral, E.E. Reactive oxygen species production and mitochondrial dysfunction contribute to quercetin induced death in Leishmania amazonensis. PLoS ONE 2011, 8, e14666. [CrossRef] [PubMed] 
28. Cataneo, A.H.D.; Tomiotto-Pellissier, F.; Miranda-Sapla, M.M.; Assolini, J.P.; Panis, C.; Kian, D.; Yamauchi, L.M.; Simão, A.N.C.; Casagrande, R.; Pinge-Filho, P.; et al. Quercetin promotes antipromastigote effect by increasing the ROS production and anti-amastigote by upregulating Nrf2/HO-1 expression, affecting iron availability. Biomed. Pharmacother. 2019, $113,108745$. [CrossRef]

29. Sen, G.; Mukhopadhyay, S.; Ray, M.; Biswas, T. Quercetin interferes with iron metabolism in Leishmania donovani and targets ribonucleotide reductase to exert leishmanicidal activity. J. Antimicrob. Chemother. 2008, 61, 1066-1075. [CrossRef]

30. Mittra, B.; Saha, A.; Chowdhury, A.R.; Pal, C.; Mandal, S.; Mukhopadhyay, S.; Bandyopadhyay, S.; Majumder, H.K. Luteolin, an abundant dietary component is a potent anti-leishmanial agent that acts by inducing topoisomerase II-mediated kinetoplast DNA cleavage leading to apoptosis. Mol. Med. 2000, 6, 527-541. [CrossRef]

31. Suganthy, N.; Devi, K.P.; Nabavi, S.F.; Braidy, N.; Nabavi, S.M. Bioactive effects of quercetin in the central nervous system: Focusing on the mechanisms of actions. Biomed. Pharmacother. 2016, 84, 892-908. [CrossRef] [PubMed]

32. Costa, S.L.; Silva, V.D.A.; Souza, C.S.; Santos, C.C.; Paris, I.; Muñoz, P.; Segura-Aguilar, J. Impact of plant-derived flavonoids on neurodegenerative diseases. Neurotox. Res. 2016, 30, 41-52. [CrossRef] [PubMed]

33. Li, Y.; Yao, J.; Han, C.; Yang, J.; Chaudhry, M.T.; Wang, S.; Liu, H.; Yin, Y. Quercetin, inflammation and immunity. Nutrients 2016, 8, 167. [CrossRef] [PubMed]

34. Hosseinzade, A.; Sadeghi, O.; Biregani, A.N.; Soukhtehzari, S.; Brandt, G.S.; Esmaillzadeh, A. Immunomodulatory effects of flavonoids: Possible induction of T CD4+ regulatory cells through suppression of mTOR pathway signaling activity. Front. Immunol. 2019, 10, 51. [CrossRef] [PubMed]

35. Chen, Y.C.; Shen, S.C.; Lee, W.R.; Hou, W.C.; Yang, L.L.; Lee, T.J. Inhibition of nitric oxide synthase inhibitors and lipopolysaccharide induced inducible NOS and cyclooxygenase-2 gene expressions by rutin, quercetin, and quercetin pentaacetate in RAW 264.7 macrophages. J. Cell Biochem. 2001, 82, 537-548. [CrossRef] [PubMed]

36. Sakao, K.; Fujii, M.; Hou, D.X. Clarification of the role of quercetin hydroxyl groups in superoxide generation and cell apoptosis by chemical modification. Biosci. Biotechnol. Biochem. 2009, 73, 2048-2053. [CrossRef]

37. Silva, A.B.; Coelho, P.L.C.; Amparo, J.A.O.; Carneiro, M.M.A.A.; Borges, J.M.P.; Souza, C.S.; Costa, M.F.D.; Mecha, M.; Rodriguez, C.G.; Silva, V.D.A.; et al. The flavonoid rutin modulates microglial/macrophage activation to a CD150/CD206 M2 phenotype. Chem.-Biol. Interact. 2017, 274, 89-99. [CrossRef]

38. Kim, M.; Park, Y.; Cho, S.; Burapan, S.; Han, J. Synthesis of alkyl quercetin derivatives. J. Korean Soc. Appl. Biol. Chem. 2015, 58, 343-348. [CrossRef]

39. Bao, D.; Wang, J.; Pang, X.; Liu, H. Protective effect of quercetin against oxidative stress-induced cytotoxicity in rat pheochromocytoma (PC-12) Cells. Molecules 2017, 22, 1122. [CrossRef]

40. Bispo da Silva, A.; Coelho, P.L.C.; Oliveira, M.N.; Oliveira, J.L.; Amparo, J.A.O.; Silva, K.C.; Soares, J.R.P.; Pitanga, B.P.S.; Souza, C.S.; Lopes, G.P.F.; et al. The flavonoid rutin and its aglycone quercetin modulate the micróglia inflammatory profile improving antiglioma activity. Brain Behav. Immun. 2020, 85, 170-185. [CrossRef]

41. Zamin, L.L.; Filippi-Chiela, E.C.; Dillenburg-Pilla, P.; Horn, F.; Salbego, C.; Lenz, G. Resveratrol and quercetin cooperate to induce senescence-like growth arrest in C6 rat glioma cells. Cancer Sci. 2009, 100, 1655-1662. [CrossRef] [PubMed]

42. Nna, V.U.; Usman, U.Z.; Ofutet, E.O.; Owu, D.U. Quercetin exerts preventive, ameliorative and prophylactic effects on cadmium chloride-induced oxidative stress in the uterus and ovaries of female Wistar rats. Food Chem. Toxicol. 2017, 102, 143-155. [CrossRef] [PubMed]

43. Bi, Y.; Shen, C.; Li, C.; Liu, Y.; Gao, D.; Shi, C.; Peng, F.; Liu, Z.; Zhao, B.; Zheng, Z.; et al. Inhibition of autophagy induced by quercetin at a late stage enhances cytotoxic effects on glioma cells. Tumour Biol. 2016, 37, 3549-3560. [CrossRef] [PubMed]

44. Dell'Albani, P.; Di Marco, B.; Grasso, S.; Rocco, C.; Foti, M.C. Quercetin derivatives as potent inducers of selective cytotoxicity in glioma cells. Eur. J. Pharm. Sci. 2017, 101, 56-65. [CrossRef] [PubMed]

45. Chen, T.J.; Jeng, J.Y.; Lin, C.W.; Wu, C.Y.; Chen, Y.C. Quercetin inhibition of ROS-dependent and -independent apoptosis in rat glioma C6 cells. Toxicology 2006, 223, 113-126. [CrossRef] [PubMed]

46. Coelho, P.L.C.; Freitas, S.R.V.B.; Pitanga, B.P.S.; Silva, V.D.A.; Oliveira, M.N.; Grangeiro, M.S.; Souza, C.S.; El-Bachá, R.S.; Costa, M.F.D.; Barbosa, P.R.; et al. Flavonoids from the Brazilian plant croton betulaster inhibit the growth of human glioblastoma cells and induce apoptosis. Braz. J. Pharmacog. 2016, 26, 34-43. [CrossRef]

47. Costa, S.L. Antiglioma potential of flavonoids. J. Bioanal. Biomed. 2014, 6, 1-3.

48. Dorman, H.J.D.; Hiltunen, R. Fe(III) reductive and free radical-scavenging properties of summer savory (Satureja hortensis L.) extract and subfractions. Food Chem. 2004, 88, 193-199. [CrossRef]

49. Guedes, C.E.S.; Dias, B.R.S.; Petersen, A.L.D.O.A.; Cruz, K.P.; Almeida, N.J.; Andrade, D.R.; Menezes, J.P.B.; Borges, V.M.; Veras, P.S.T. In vitro evaluation of the anti-leishmanial activity and toxicity of PK11195. Mem. Inst. Oswaldo Cruz 2018, 113, e170345. [CrossRef]

50. Benda, P.; Lightbody, J.; Sato, G.; Levine, L.; Sweet, W. Differentiated rat glial cell strain in tissue culture. Science 1968, 161, 370-371. [CrossRef]

51. Oliveira, D.M.; Lima, R.M.F.; Clarencio, J.; Velozo, E.S.; de Amorim, I.A.; Da Mota, T.H.A.; Costa, S.L.; Silva, F.P.; El-Bachá, R.S. The classical photoactivated drug 8-methoxypsoralen and related compounds are effective without UV light irradiation against glioma cells. Neurochem. Int. 2016, 99, 33-41. [CrossRef] 
52. Ahmed, S.A.; Gogal, R.M.; Walsh, J.E. A new rapid and simple non-radioactive assay to monitor and determine the proliferation of lymphocytes an alternative to [3H] thymidine incorporation assay. J. Immunol. Methods 1994, 170, 211-224. [CrossRef]

53. Hansen, M.B.; Nielsen, S.E.; Berg, K. Re-examination, and further development of a precise and rapid dye method for measuring cell growth/cell kill. J. Immunol. Methods 1989, 119, 203-210. [CrossRef]

54. Hora, N.R.S.; Santana, L.F.; Silva, V.D.A.; Costa, S.L.; Zambotti-Villela, L.; Colepicolo, P.; Ferraz, C.G.; Ribeiro, P.R. Identification of bioactive metabolites from corn silk extracts by a combination of metabolite profiling, univariate statistical analysis and chemometrics. Food Chem. 2021, 365, 130479. [CrossRef] [PubMed]

55. Green, L.C.; Wagner, D.A.; Glogowski, J.; Skipper, P.L.; Wishnok, J.S.; Tannenbaum, S.R. Analysis of nitrate, nitrite, and [15 N] nitrate in biological fluids. Anal. Biochem. 1982, 126, 131-138. [CrossRef] 